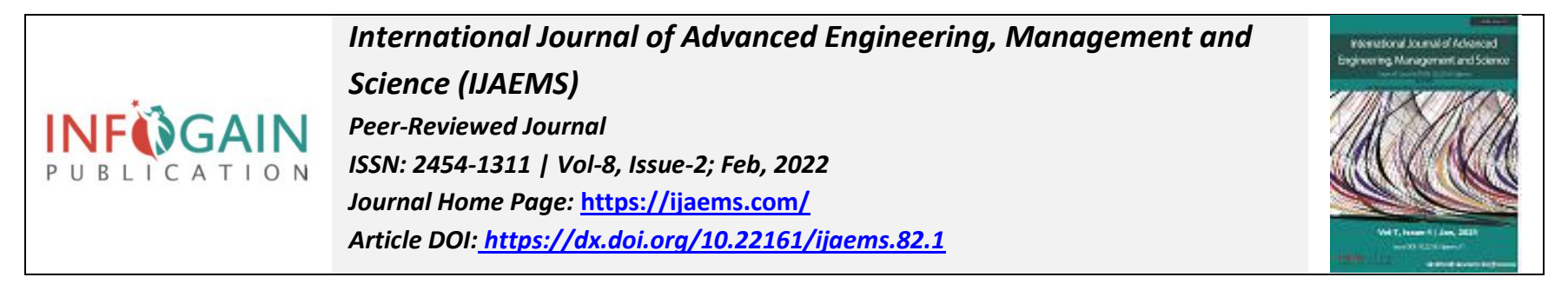

\title{
Punching strengthening of reinforced concrete slab- Column connection using different techniques
}

\author{
Gamal I. Khaleel ${ }^{1}$, Ahmed H.Abdel Kareem², Ahmed S. Debaiky ${ }^{3}$, Eslam G.Abd El- \\ $\operatorname{maogod}^{4}$
}

${ }^{1,2,3}$ Professor, Faculty of Engineering, Benha University, Egypt.
${ }^{4}$ Teaching Assistant, Faculty of Engineering, Benha University, Egypt.

Received: 11 Dec 2021; Received in revised form: 03 Feb 2022; Accepted: 10 Feb 2022; Available online: 18 Feb 2022

\begin{abstract}
This paper presents experimental data and results on the effect of externally bonded fiberreinforced polymer (FRP) with studs from FRB on the punching shear behavior of interior slab-column connections. A total of sixteen square slabs with a concentric column were constructed and tested. One specimen act as a control, and the others specimens strengthened with three different strengthening techniques. The first technique consists of 6 slabs strengthened with external FRB strips with different configuration (skewed or orthogonal) and different location from column face (offset or adjacent) and the second technique consist of 4 slab strengthened with external FRB strips with studs from FRP located on both side of the strips with spacing $100 \mathrm{~mm}$ and cross at intersection of strips which act as shear reinforcement and wrapping FRP strips to delayed debonding of FRP and improve the structure behavior of strengthened connection. The third technique consists of 5 slabs strengthened with external FRB and steel plates with different size $350 \times 350 \mathrm{~mm}$ and $450 \times 450 \mathrm{~mm}$ at the center of the slab. The test variables were the location of FRP strips (adjacent or offset column face), the number of strips layer and the orientation angle of the strips (Orthogonal and Skewed), and the type of materials (GFRP, CFRP, Steel). Size of plate $350 \times 350 \mathrm{~mm}$ or $450 \times 450 \mathrm{~mm}$ and method of strengthening. The test results clearly showed that FRP with studs strengthening leads to significant improvements in the structural behavior of slabcolumn connections. The increase in punching capacity of strengthened slabs was up to 48\%, while the increase in stiffness was up to $92 \%$ compared to the control slab.
\end{abstract}

Keywords-Concrete, Flat Slab, FRP, Punching, slab-column connections, strengthening.

\section{INTRODUCTION}

Flat concrete slabs are a typical form of flooring systems used in a wide range of buildings such as offices, warehouses, and parking garages. Flat slabs are directly supported on columns providing more vertical clear space due to the absence of beams. The connection between the slab and the column in this system is generally the most critical part due to its vulnerability to punching shear failure. Punching shear failures are very brittle in nature and take place within small deflections. Punching strength in slabs can become insufficient due to several reasons such as change of building use, corrosion of reinforcement, and construction or design errors. Punching shear is characterized by cracking within the slab around the This article can be downloaded from here: www.ijaems.com

C2022 The Author(s). Published by Infogain Publication. column with a truncated cone-shaped element being displaced. In general, the predicted punching failure load is governed largely by the flexural characteristics of the slab. Over the past decade, a significant amount of research has dealt with various strengthening techniques for concrete slab-column connections to prevent sudden punching shear failure. FRP can be used in two methods; externally installed [1] [2] and internally installed [3] [4]. The FRP externally strengthened system consists of one or more FRP sheets / strips bonded to the tension side of the slab using epoxy adhesive. This strengthening method increases the flexural reinforcement and therefore increases the punching shear strength by delaying the shear cracks formation. The common failure for external strengthening

This work is licensed under a Creative Commons Attribution 4.0 License. http://creativecommons.org/licenses/by/4.0/ 
technique is the premature debonding of FRP, which could be delayed and improve the structural behavior of strengthened connection by providing end anchorage to the externally bonded FRP [5].Post-installation of FRP studs or FRP shear dowels, as shear reinforcement, in drilled holes filled with suitable epoxy grout falls into internal strengthened method for slab-columns connections. The drilled holes, to insert shear reinforcement, in the critical punching shear area of the slab near the column could further damage the degenerated slab. The near surface mounted (NSM) for strengthening RC elements. In this strengthening method, grooves are cut in the concrete cover of the structural elements and are partially filled by a suitable bonding adhesive. After that, the reinforcing bars are inserted in the grooves and covered by the bonding adhesive. Finally, the surface of the structure element is leveled. The strengthening of RC beams and slabs in flexure by NSM technique using FRP bars [6] [7] [8].Another research investigated the shear performance of RC beams strengthened by the NSM technique using FRP bars in the form of external stirrups [9] [10].

The main objective of this study is to investigate the effectiveness of using combination of FRP strips with studs from FRP which wrapping FRP strips to delayed debonding of FRP strips, act as shear reinforcement and improve structural behavior against punching shear failure. This paper presents the experimental results of the study and a comparison of the test data with an analytical model.

\section{EXPERIMENTAL PROGRAM}

\subsection{Specimens and test matrix}

Sixteen RC slab-column connections subjected to punching loading were constructed and tested in the experimental program. The main objective of the test program was to investigate the effectiveness of using combination of FRP strips with studs from FRP. Studs wrapping FRP strips to delayed debonding of FRP strips, act as shear reinforcement and improve structural behavior against punching shear failure. One specimen act as a control, and the others specimens strengthened with three different strengthening techniques. The first technique consists of 6 slabs strengthened with external FRB strips with different configuration (skewed or orthogonal) and different location from column face (offset or adjacent) and the second technique consist of 4 slab strengthened with external FRB strips with studs from FRP located on both side of the strips with spacing $100 \mathrm{~mm}$ and cross at intersection of strips which act as shear reinforcement and wrapping FRP strips to delayed debonding of FRP and improve the structure behavior of strengthened connection. The third technique consists of 5 slabs strengthened with external FRB and steel plates with different size $350 \times 350$ $\mathrm{mm}$ and $450 \times 450 \mathrm{~mm}$ at the center of the slab.

The description of strengthening schemes and nomenclatures for tested specimens is gives in Table 1. The first letter of the nomenclature of the specimen (S) standing for slab. The second letter points to the strengthening technique, where $(\mathrm{P})$ for externally bonded plate and (S) for externally bonded strips. The third letter refers to the strengthening configuration relative to the orientation of the slab reinforcement, $(\mathrm{O})$ for orthogonal and $(\mathrm{K})$ for skewed. The fourth letter indicates the location of strips from the column (F) offset column face (A) adjacent to column face. The fifth letter point to type of material used in strengthening $(\mathrm{G})$ for glass fiber $(\mathrm{C})$ for carbon fiber and $(\mathrm{S})$ for the steel.The sixth letter point to the presence of studs or not (S) for studs. Figure. 1 shows the strengthening schemes used in the presents study.

All the specimens had the same dimensions and steel reinforcement details, as shown in Figure. 2. The slab dimensions were $1150 \times 1150 \mathrm{~mm}$ and $100 \mathrm{~mm}$ thick. The specimens were designed to be supported along the four edges with clean spans $1000 \mathrm{~mm}$ in both directions. A column stub $150 \times 150 \mathrm{~mm}$ was cast monolithically at the center of the slab. To simulate the actual interior slabcolumn connections, the column extended $150 \mathrm{~mm}$ up and $50 \mathrm{~mm}$ down the slab faces, and the slab reinforced with top and bottom meshes. The slabs were reinforced using high tensile steel bars of $10 \mathrm{~mm}$ diameter. The bottom mesh was $11 \varnothing 10$ and the top mesh was $7 \varnothing 10$. The columns were reinforced with vertical high tensile steel bars $\emptyset 12$ in each corner of the column and normal mild steel stirrups $8 \mathrm{~mm}$ every $100 \mathrm{~mm}$. A clear concrete cover of $20 \mathrm{~mm}$ and $15 \mathrm{~mm}$ was kept at bottom and top of the slabs, respectively. 


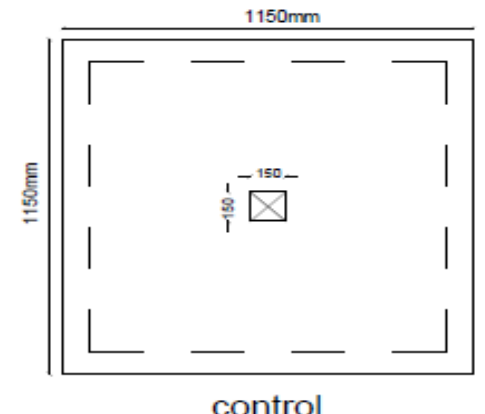

control

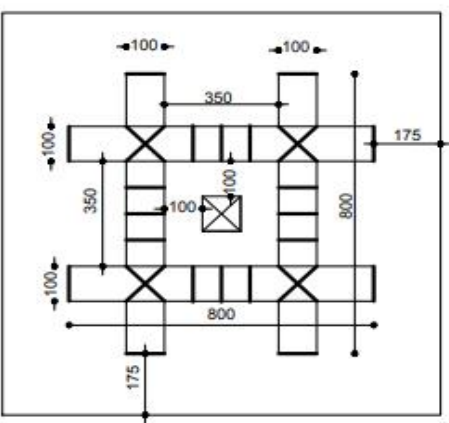

S-S-O-F-G-S

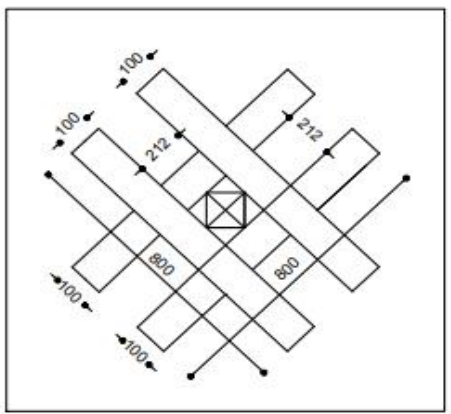

S-S-K-A-G

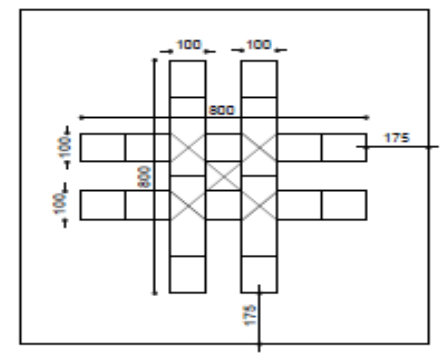

S-S-O-A-G-S

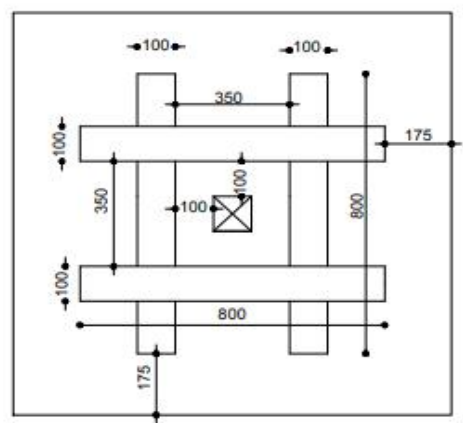

S-S-O-F-G-S

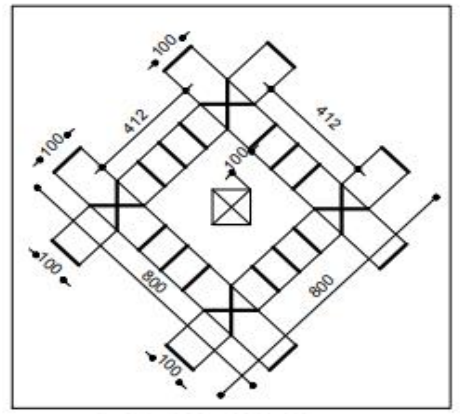

S-S-K-F-G-S

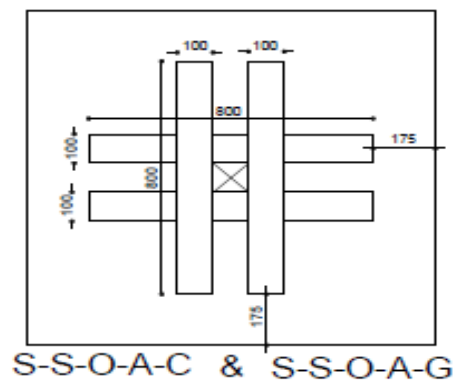

S-S-O-A-G*

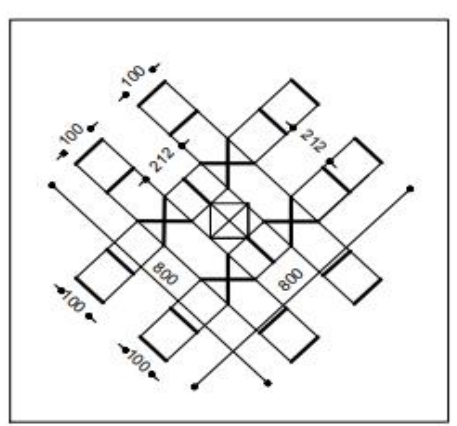

S-S-K-A-G-S

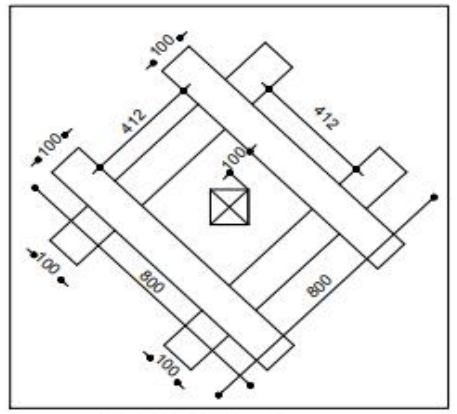

S-S-K-F-G

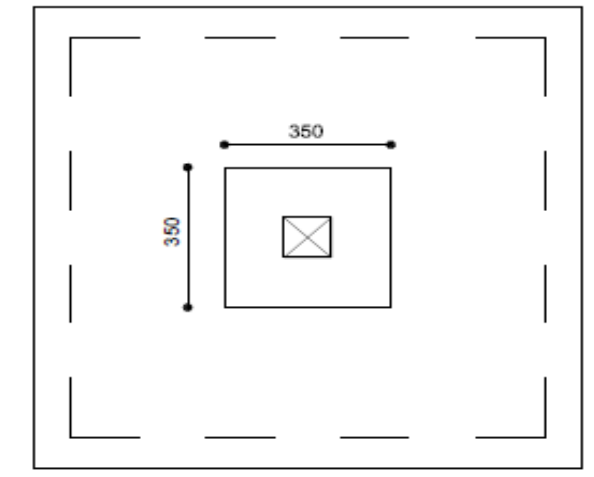

S-P-O-F-G \& S-P-O-F-S

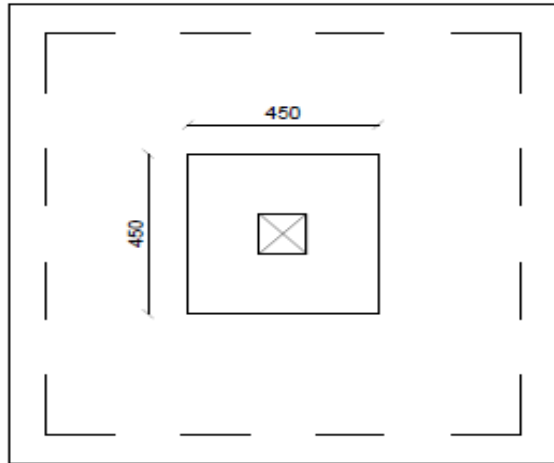

S-P-O-F-C \& S-P-O-F-G**

S-P-O-F-S

Fig.1. Strengthening Schemes (all dimensions in $\mathrm{mm}$ ) 
Table 1. Test Matrix

\begin{tabular}{|c|c|c|c|c|c|c|}
\hline & Group & Slab ID & Fabrictype & $\begin{array}{l}\text { Number of } \\
\text { FRPlayers }\end{array}$ & $\begin{array}{c}\text { studs type } \\
\text { with spacing } \\
100 \mathrm{~mm}\end{array}$ & $\begin{array}{l}\text { Description ofstrengthening } \\
\text { configuration }\end{array}$ \\
\hline 1 & & $\mathrm{~S}$ & - & - & - & Control; no strengthening \\
\hline 2 & & $-\mathrm{G}-\mathrm{S}$ & Glass & 2 & Glass & \\
\hline 3 & \multirow{3}{*}{ group 1} & S-S-O-A-C & Carbon & 2 & - & \multirow{3}{*}{ gonal; adjacent tocolumn face } \\
\hline 4 & & S-S-O-A-G & Glass & 2 & - & \\
\hline 5 & & S-S-O-A-G* & Glass & 3 & - & \\
\hline 6 & & S-S-O-F-G-S & Glass & 2 & Glass & hogonal; offsetcolumn face (d) \\
\hline 7 & group 2 & S-S-O-F-G & Glass & 2 & - & \\
\hline 8 & \multicolumn{2}{|c|}{$-A-G-S$} & Glass & 2 & Glass & \multirow[t]{2}{*}{ wed; adjacent tocolumn edge } \\
\hline 9 & group 3 & S-S-K-A-G & Glass & 2 & - & \\
\hline$\overline{10}$ & & S-S-K-F-G-S & Glass & 2 & Glass & \multirow[t]{2}{*}{ Iffset columnedge $(\mathrm{d})$} \\
\hline 11 & group 4 & S-S-K-F-G & Glass & 2 & - & \\
\hline$\overline{12}$ & & S-P-O-F-G & $\begin{array}{c}\text { Glass } \\
350 \times 350\end{array}$ & 2 & - & \multirow{3}{*}{ Center of the slab } \\
\hline 13 & & S-P-O-F-G** & $\begin{array}{c}\text { Glass } \\
450 \mathrm{X} 450\end{array}$ & 2 & - & \\
\hline 14 & group5 & S-P-O-F-C & $\begin{array}{c}\text { Carbon } \\
450 X 450\end{array}$ & 2 & - & \\
\hline 15 & & S-P-O-F-S & $\begin{array}{c}\text { Steel } \\
350 \times 350\end{array}$ & - & - & \multirow[t]{2}{*}{ Center of the slab } \\
\hline 16 & group6 & S-P-O-F-S* & $\begin{array}{c}\text { Steel } \\
450 \times 450\end{array}$ & - & - & \\
\hline
\end{tabular}

$\mathrm{G}^{*}:$ specimen strengthened with three layers

$\mathrm{G}^{* *}$ : specimen strengthened with glass plate with size $450 \times 450 \mathrm{~mm}$

$\mathrm{S}^{*}$ : specimen strengthened with steel plate with size $450 \times 450 \mathrm{~mm}$ 


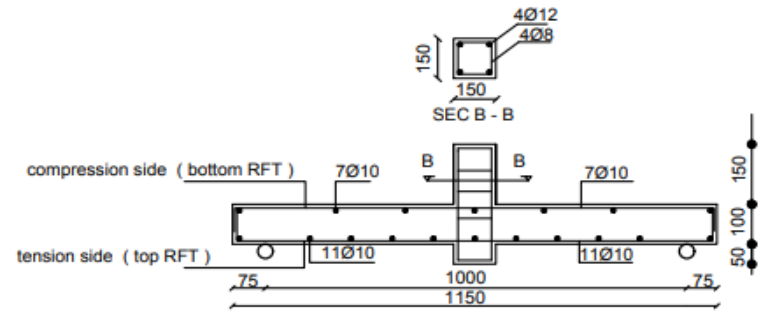

(i) With bot column

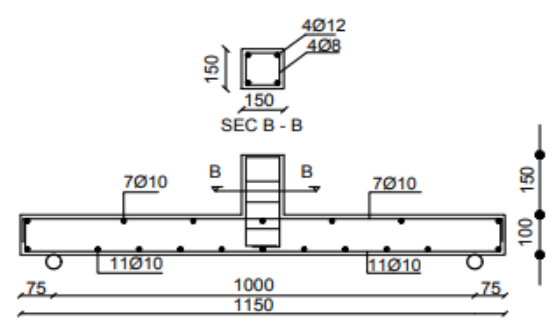

(ii) Without bot column

(a) SEC A - A

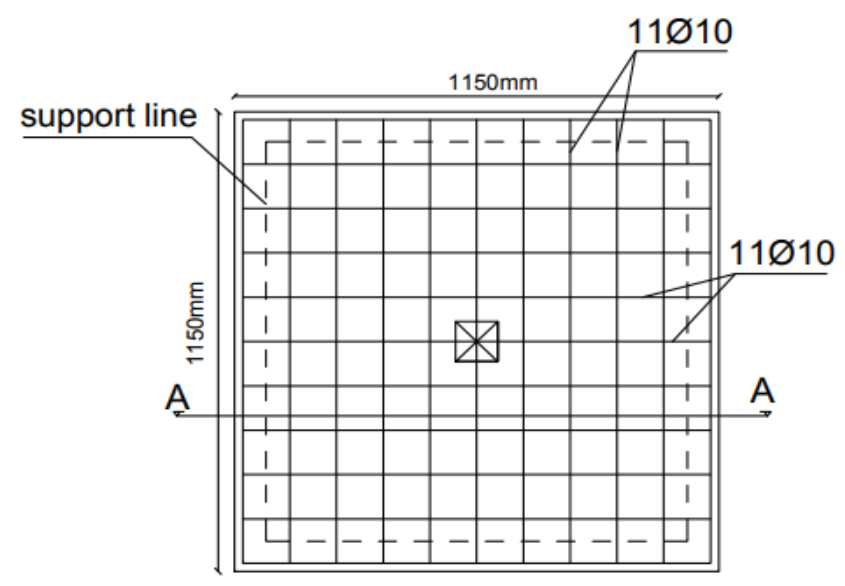

(b) Bottom Reinforcement

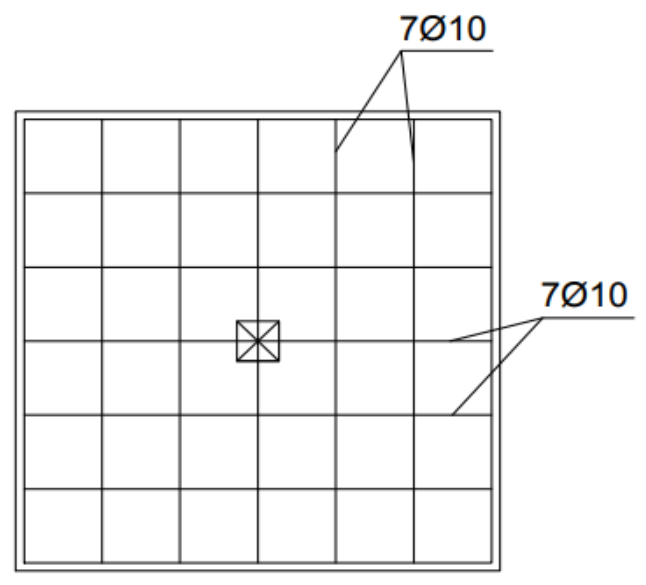

(c) Top Reinforcement

Fig.2. Dimensions and reinforcement details for tested specimens (All dimensions in mm)

\subsection{Material properties}

\subsubsection{Concrete}

The concrete mixture used in the tested specimens consists of Ordinary Portland Cement (OPC-42.5 grade), natural sand with 2.6 fineness moduli and crushed dolomite with maximum aggregate size $16 \mathrm{~mm}$. the target compressive strength (fcu) at 28 days was 30 Map. The actual fcu was obtained at the day of testing and based on cubes $(150 \times 150 \times 150 \mathrm{~mm})$ were casted and cured with the tested specimens.

\subsubsection{GFRP Sheets and CFRP Sheets}

CFRP strips used in this study are SikaWrap230, which is a product of Sika Company. The strips were bonded to the bottom face of the slabs using epoxy Sikadur-330. Table 2 gives the mechanical properties of the carbon fiber, glass fiber, glass studs and steel according to the manufacturer. The width of the strips was $100 \mathrm{~mm}$.

\subsubsection{Strengthening procedures}

\subsubsection{EB Strengthening technique}

The CFRP and GFRP strips externally strengthened the concrete slab, were cutoff $800 \mathrm{~mm}$ long and $100 \mathrm{~mm}$ width and were placed around column in orthogonal or skew orientation, as shown in Fig.1. Angle grinder with a wire brush was used to rough the concrete surface, where the strips would be placed. The surface was cleaned from loose materials using a vacuum cleaner. Then, the epoxy adhesive (Sikadur-330) was applied on both strips surfaces and the marked locations on the concrete surface. The strips were then pressed on to the concrete surface using a smaller roller. The excess epoxy was squeezed from the slides and cleaned. 


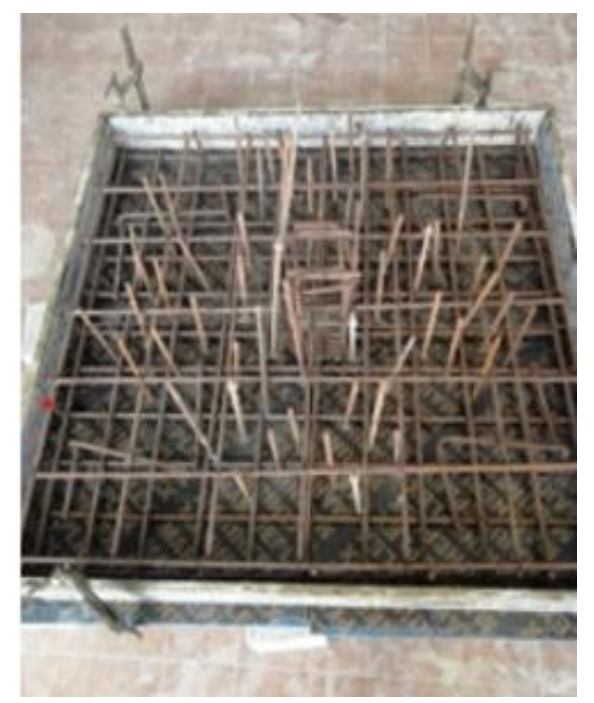

location of holes before casting

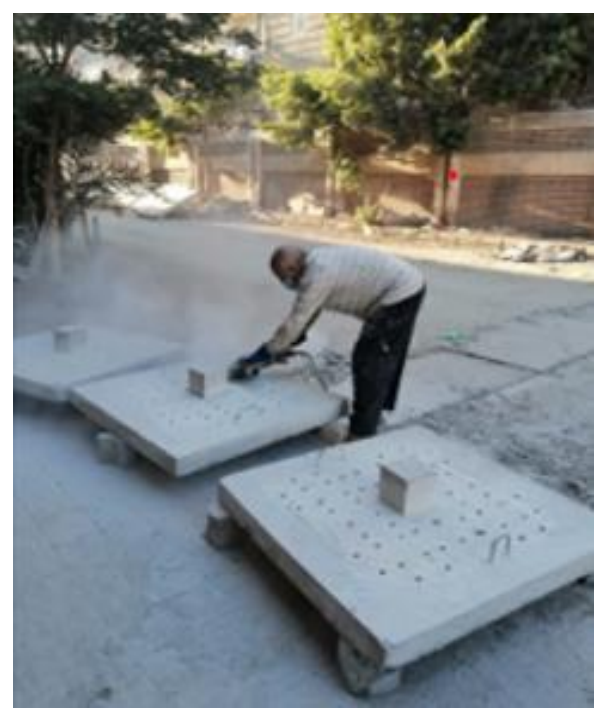

levelling the bottom surface of the slab by using grinder

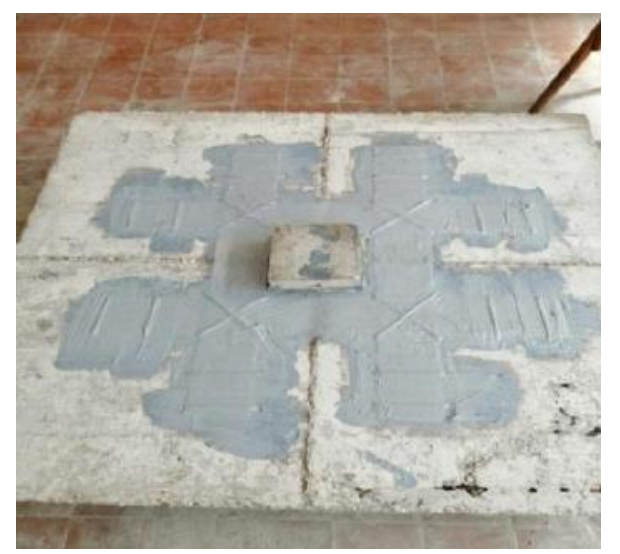

Just after bonded the studs by using epoxy

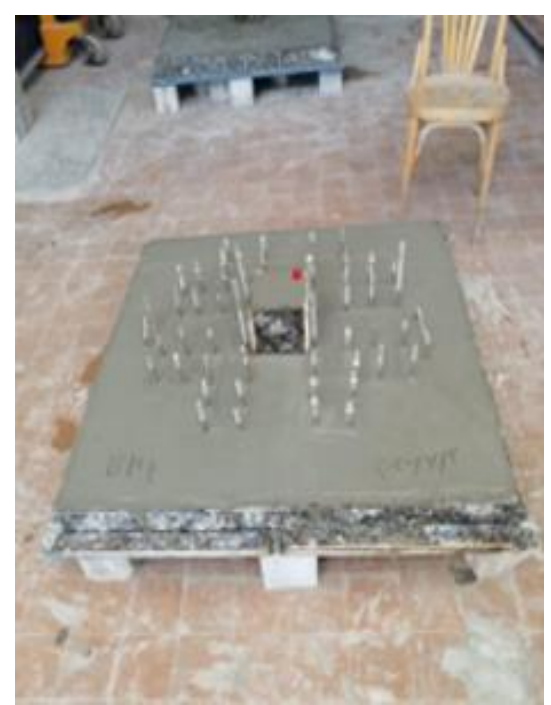

just after casting concrete

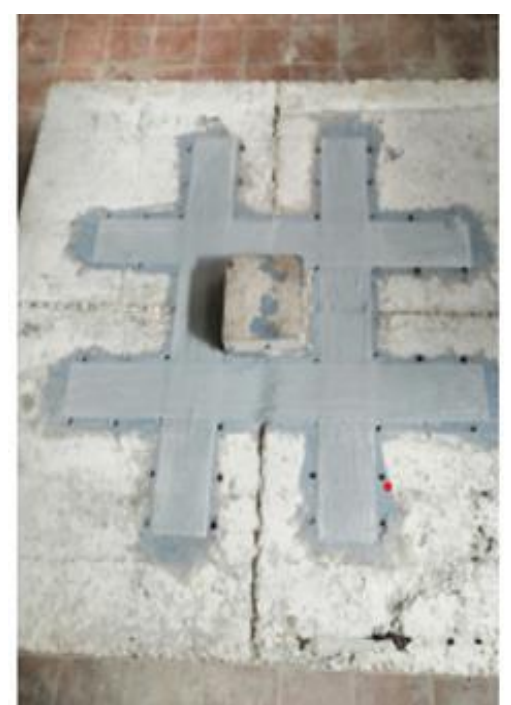

bonded the FRP strips by using epoxy

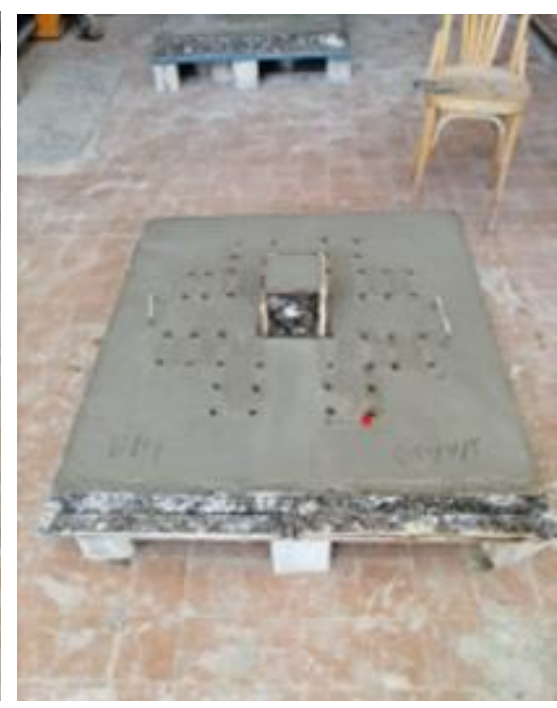

removing small pieces of steel bars

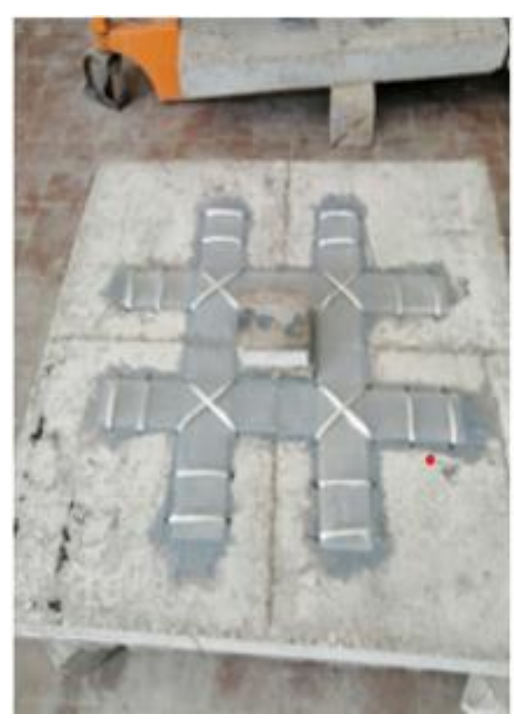

fixed the studs on their places

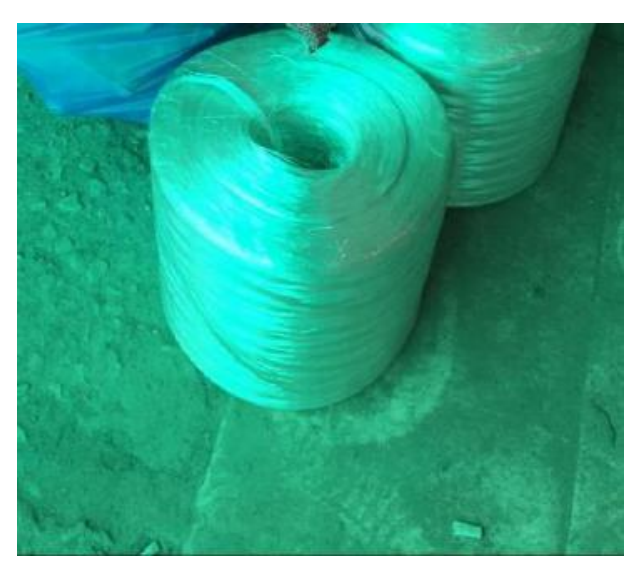

the rolls of GFRP studs

Fig.3. Strengthening Procedures using EB technique with studs 


\subsubsection{EB Strengthening technique with studs}

The same previous technique but make holes on the side of strips which penetrating overall slab depth the holes were formed during concrete casting using small pieces of steel bar, as indicated previously. After casting and curing the specimens, the holes were cleaned from the steel pieces and loose materials. Then the epoxy Sikador-330 filled halfway the hole, GFRP studs was slightly inserted forcing the epoxy to fill completely between the sides of the hole and the studs. A second layer of epoxy was applied to fill the hole and the residue epoxy was removed, and the surface was leveled. studs from FRP located on both side of the strips with spacing $100 \mathrm{~mm}$ and cross at intersection of strips which act as shear reinforcement and wrapping FRP strips to delayed debonding of FRP and improve the structure behavior of strengthened connection Fig. 3 shows the strengthening procedures for a specimen using EP technique with studs.

\subsubsection{Test-up and Instrumentation}

The specimens were centrally loaded using a hydraulic jack, $1000 \mathrm{kN}$ maximum capacity, connected to an electric pump, and hanged in a rigid reaction frame, $1000 \mathrm{kN}$ maximum capacity. The specimens were supported on steel rod bars along all four sides to behave as simply supported. The rod bars were welded to I-shaped steel beams. The load was distributed to the head of column stub using a thick steel plate. The applied load was record using a load cell of $1000 \mathrm{kN}$ maximum capacity placed under the hydraulic jack. To monitor the deflection, Three Linear Variable Differential Transducers (LVDT) were placed beneath the center of the column stub and quarter-span of the slab. For each strengthened specimen, one strain gauge was attached to the strips and the other attached to concrete surface. The cracks propagation was marked with applied load increasing up to failure. All test data were captured using data acquisition system and recorded on a computer at intervals of two seconds. Figure. 4 illustrates the test set-up.

Table 2. Dimensions and characteristic properties of GFRP, CFRP and STEEL

\begin{tabular}{lccc}
\multicolumn{1}{c}{ Characteristic } & GFRP sheets & Characteristic & GFRP Studs \\
\hline Fabric width (mm) & 500 & Diameter & 6 \\
Fabric thickness (mm) & 0.17 & Tensile strength & 66245 \\
Tensile strength (Mpa) & 2300 & Modulus of elasticity (Mpa) & Steel Sheets \\
Modulus of elasticity (Mpa) & 76000 & Characteristic & $350 \times 350$ \\
Strain at failure & $3.0 \%$ & Sheet width (mm) & $450 \times 450$ \\
\hline Characteristic & GFRP sheets & Sheet thickness (mm) & \\
\hline Fabric width (mm) & 500 & & \\
Fabric thickness (mm) & 0.128 & & \\
Tensile strength (Mpa) & 4300 & & \\
Modulus of elasticity (Mpa) & 234000 & $1.84 \%$ & \\
Strain at failure & & & \\
\hline
\end{tabular}

\section{EXPERIMENTAL RESULTS AND DISCUSSION}

The experimental test results are summarized in Table 3. The effect of test parameters on the behavior of tested specimens under punching load will been discussed in the following sections.

\subsection{Load-deflection Relationships}

Figures.5-11 show the deflection of the column stub, located at the center of the slab, versus the applied load according to the test parameters. The curve of control specimen increased almost linear till reached the peak load, and then the load suddenly dropped due to brittle punching shear failure. The load-deflection curves for the strengthened specimens were similar to that of control specimen, except the decreasing of the load after reaching its peak value was less sharp. The load-def show increasing in the ultimate load and decreasing in the deflection at the same load for all strengthened specimens compared to the control specimen. The reduction of the deflection of the strengthened specimens compared to control specimen were qualified by measuring the deflection for all test specimens at the ultimate load of the control specimen $\left(\Delta_{\mathrm{uc}}\right)$, which listed in Table 3. 


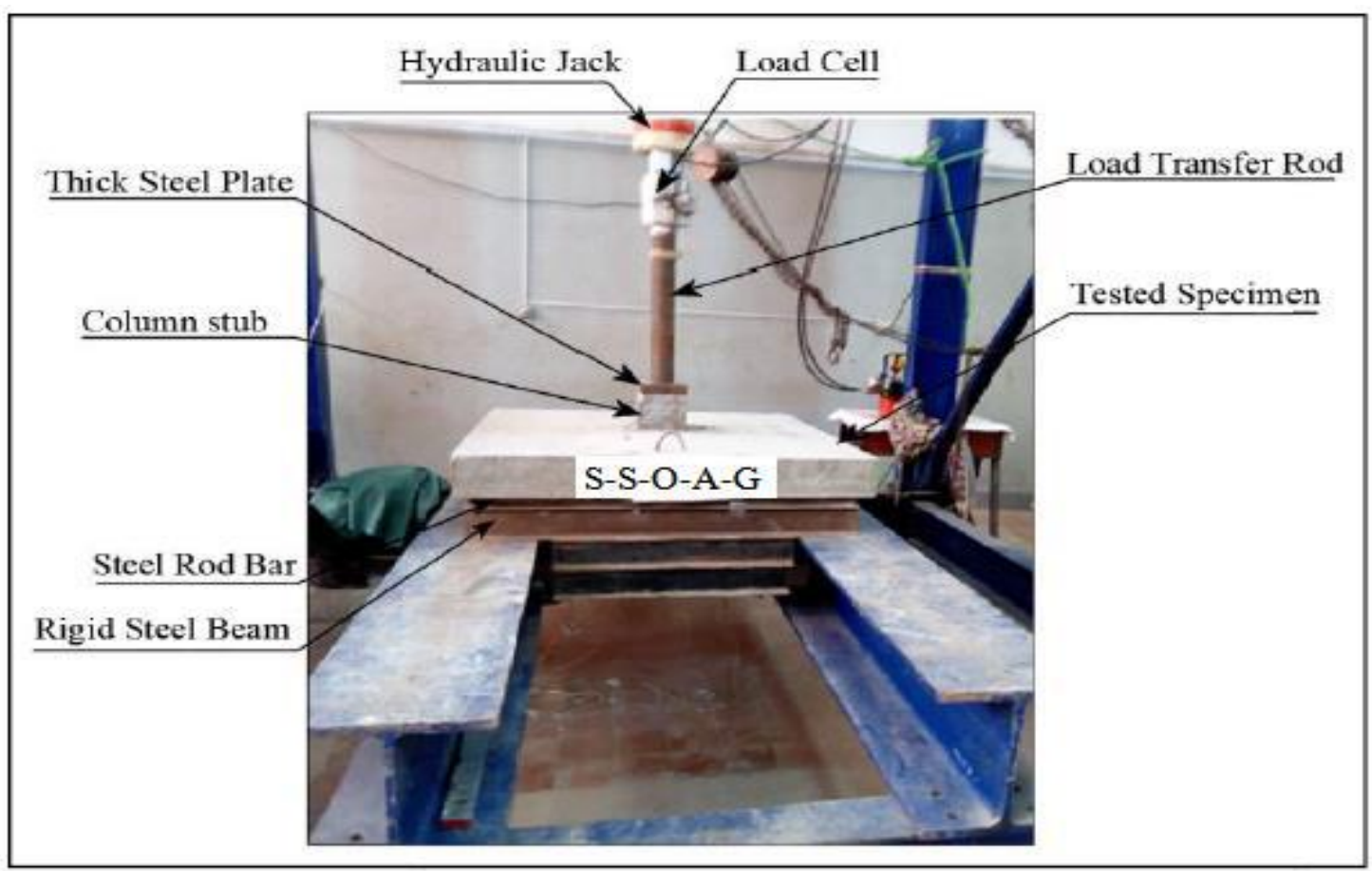

Fig.4. Test Set-up

Table 3. Summary of experimental results

\begin{tabular}{|c|c|c|c|c|c|c|c|c|c|}
\hline \multirow{2}{*}{ Slab ID } & \multirow{2}{*}{$\begin{array}{c}\text { Fcu } \\
\text { (Mpa) }\end{array}$} & \multicolumn{2}{|c|}{$1^{\mathrm{ST}}$ Cracking } & \multicolumn{2}{|c|}{ Ultimate } & \multirow{2}{*}{$\frac{\mathbf{P}_{\mathbf{u}}}{\mathbf{P}_{\text {control }}}$} & \multirow[b]{2}{*}{$\Delta_{\mathrm{uc}}$} & \multirow{2}{*}{$\begin{array}{c}\begin{array}{c}\text { Un- } \\
\text { cracked }\end{array} \\
\text { Stiffness } \\
\left(\mathbf{K}_{\mathbf{i}}\right)\end{array}$} & \multirow{2}{*}{$\begin{array}{c}\begin{array}{c}\text { Ultimate } \\
\text { Stiffness } \\
\left(\mathbf{K}_{\mathrm{U}}\right)\end{array} \\
\frac{\mathbf{P}_{\mathrm{u}}-\mathbf{P}_{c r}}{\Delta_{\boldsymbol{u}}-\Delta_{\mathrm{cr}}}\end{array}$} \\
\hline & & $\begin{array}{c}\operatorname{Load}\left(\mathbf{p}_{\text {cr }}\right. \\
) \mathbf{K N}\end{array}$ & $\begin{array}{c}\operatorname{Deflection}(\Delta \\
\text { rr)mm }\end{array}$ & $\begin{array}{c}\operatorname{Load}(p \\
\text { u)KN }\end{array}$ & $\begin{array}{c}\operatorname{Deflection}\left(\Delta_{\mathrm{cr}}\right) \\
\mathbf{m m}\end{array}$ & & & & \\
\hline$S$ & 31.80 & 51 & 2.94 & 172 & 13.30 & 1 & 13.30 & 17.35 & 11.67 \\
\hline S-S-O-A-G & 32.40 & 75 & 2.92 & 188.89 & 10.08 & 1.1 & 9.17 & 25.68 & 15.90 \\
\hline S-S-O-A-G* & 32.20 & 68 & 2.88 & 195.89 & 13.04 & 1.14 & 11.47 & 23.61 & 12.52 \\
\hline S-S-O-A-C & 31.50 & 51 & 2.93 & 191.49 & 13.10 & 1.11 & 11.56 & 17.40 & 13.81 \\
\hline S-S-O-A-G-S & 32.45 & 77 & 2.285 & 220.69 & 11.06 & 1.28 & 8.73 & 23.44 & 18.48 \\
\hline S-S-O-F-G-S & 32.20 & 75 & 2.55 & 240.30 & 11.90 & 1.40 & 8.62 & 29.44 & 17.67 \\
\hline S-S-O-F-G & 33.0 & 72 & 2.68 & 214.29 & 12.96 & 1.25 & 10.52 & 26.86 & 13.84 \\
\hline S-S-K-A-G-S & 32.80 & 63 & 2.20 & 232.49 & 13.05 & 1.35 & 9.78 & 28.64 & 15.62 \\
\hline S-S-K-A-G & $\begin{array}{c}31.87 \\
0\end{array}$ & 65 & 2.44 & 202.40 & 10.136 & 1.18 & 8.73 & 26.64 & 17.85 \\
\hline S-S-K-F-G-S & 32.50 & 67 & 2.49 & 254.34 & 11.90 & 1.48 & 8.08 & 26.91 & 20.23 \\
\hline S-S-K-F-G & 33.20 & 63 & 2.78 & 227.69 & 12.82 & 1.32 & 9.68 & 21.95 & 16.55 \\
\hline S-P-O-F-G & 31.60 & 58 & 2.35 & 183.10 & 13.10 & 1.06 & 12.4 & 24.68 & 11.63 \\
\hline S-P-O-F-G** & 32.40 & 58 & 2.78 & 202.10 & 13.0 & 1.18 & 11.09 & 20.86 & 14.10 \\
\hline S-P-O-F-C & 31.40 & 53 & 2.72 & 210.0 & 11.45 & 1.22 & 9.51 & 17.98 & 16.92 \\
\hline
\end{tabular}




$\begin{array}{cccccccccc}\text { S-P-O-F-S } & 32.30 & 55 & 2.96 & 192.0 & 12.76 & 1.12 & 11.45 & 18.58 & 13.97 \\ \text { S-P-O-F-S* } & 31.70 & 56 & 2.53 & 205.10 & 11.17 & 1.19 & 9.42 & 22.13 & 17.25\end{array}$

$\Delta_{\text {uc }}$ the deflection for all test specimens at the ultimate load of the control specimen.

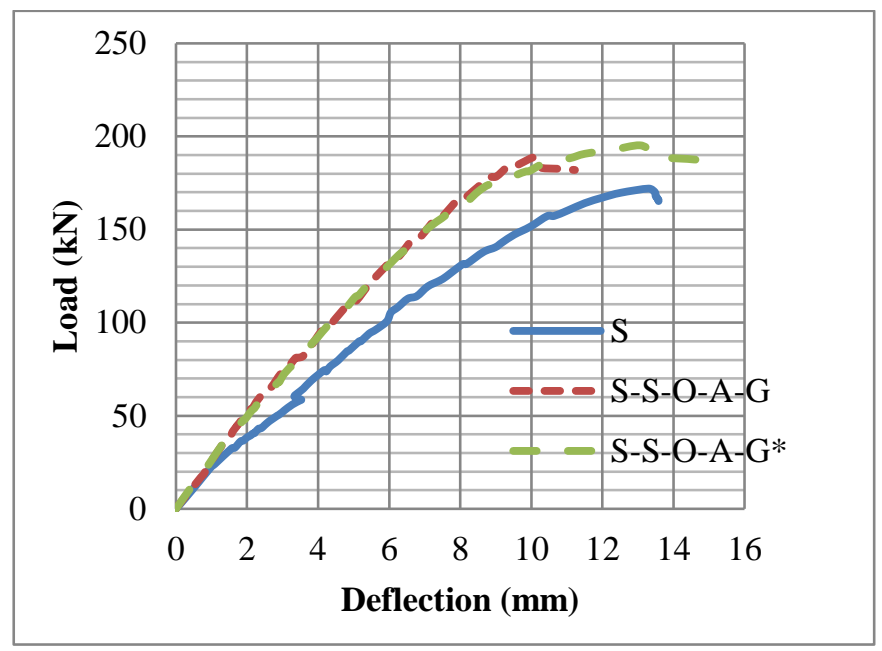

Fig.5. Central deflection comparison based on the number of strengthening layers.
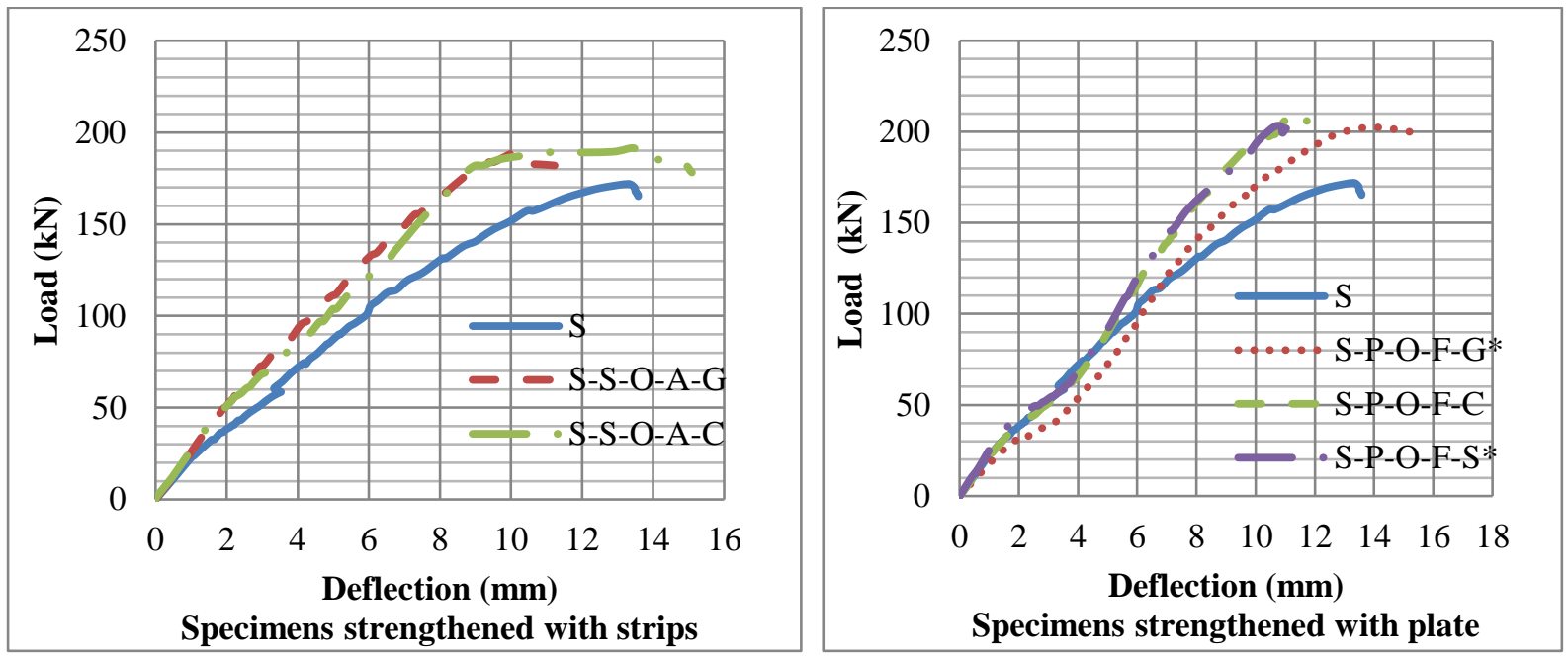

Fig.6 . Central deflection comparison based on the type of strengthened material. 

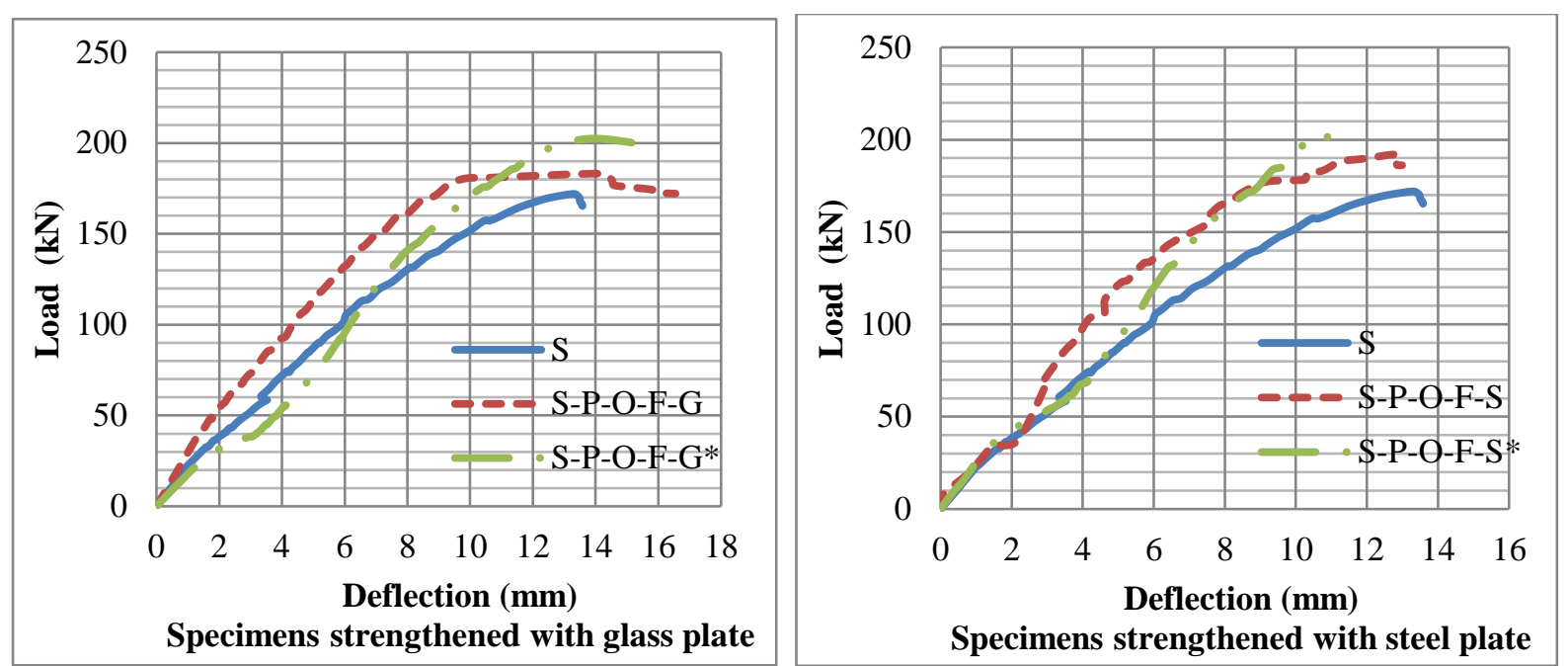

Fig.7: Central deflection comparison based on the size of steel and glass plate.
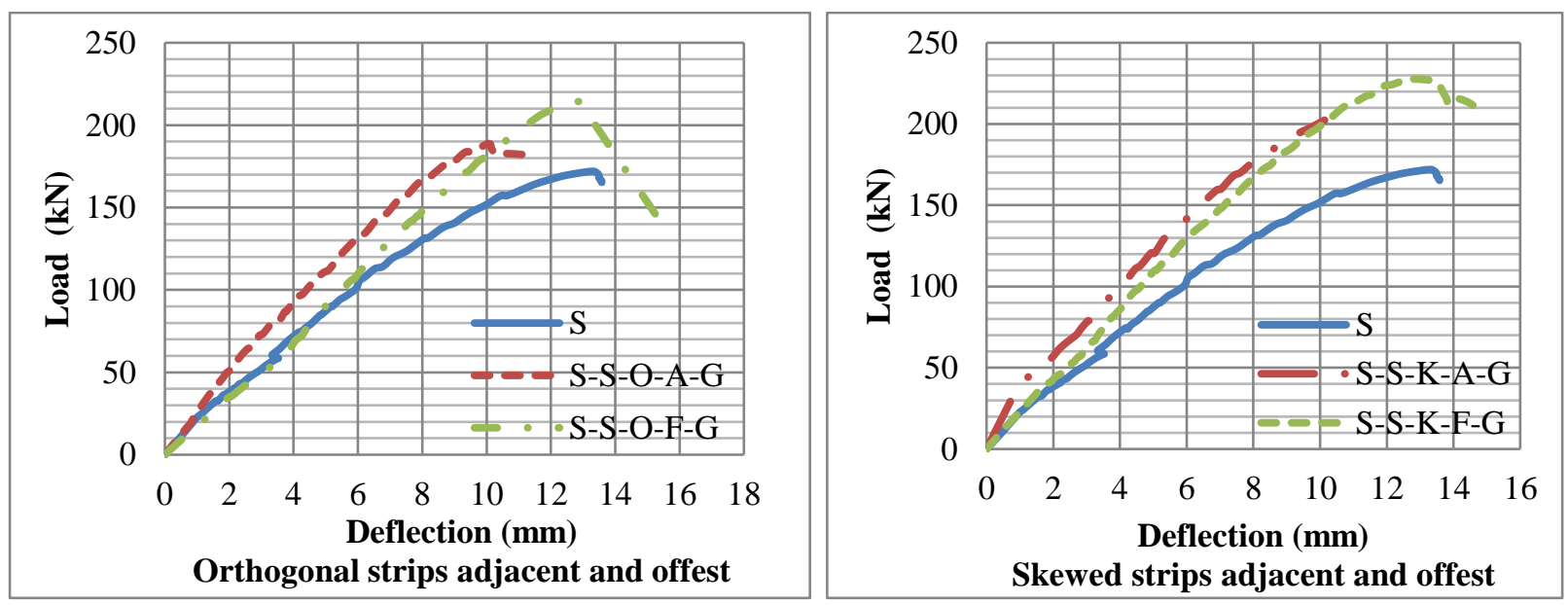

Fig.8. Central deflection comparison based on the effect location of the strips without studs
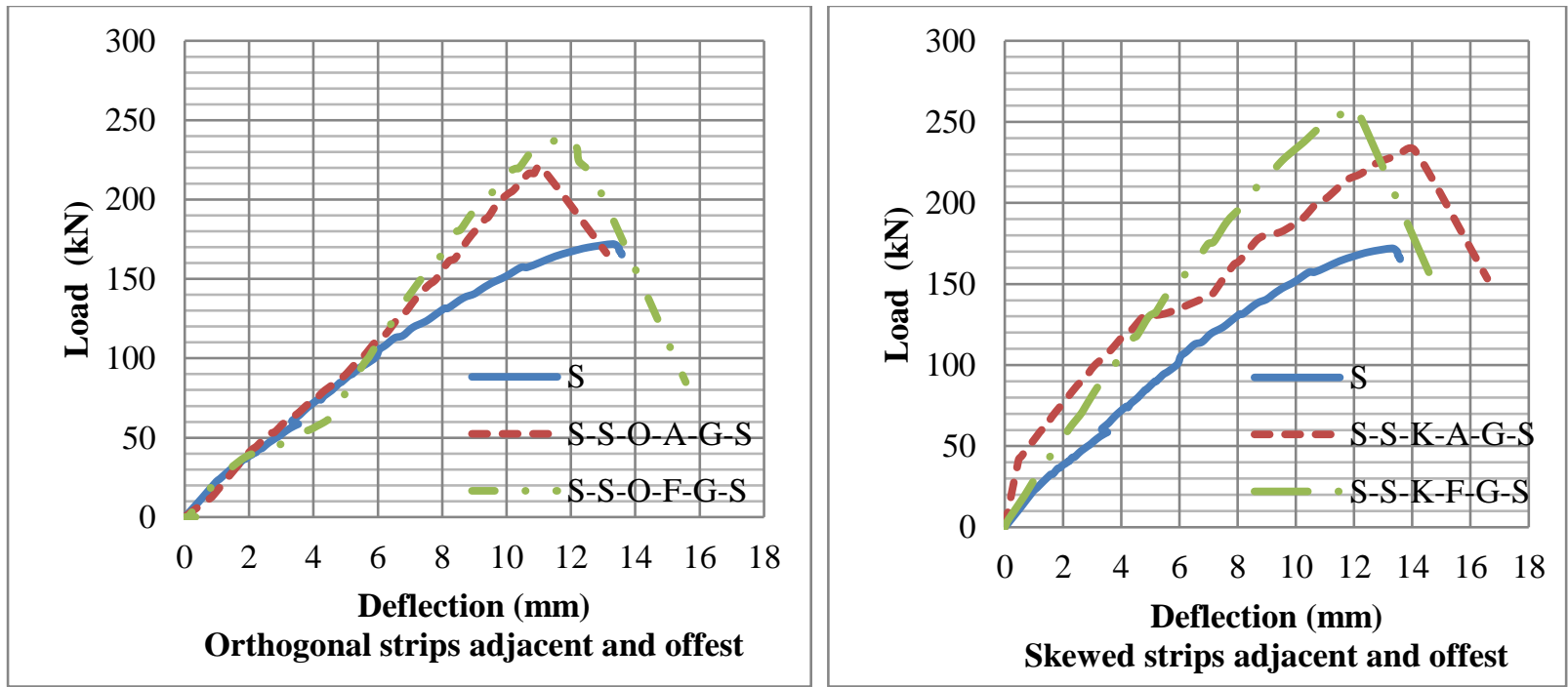

Fig.9. Central deflection comparison based on the effect location of the strips with studs 

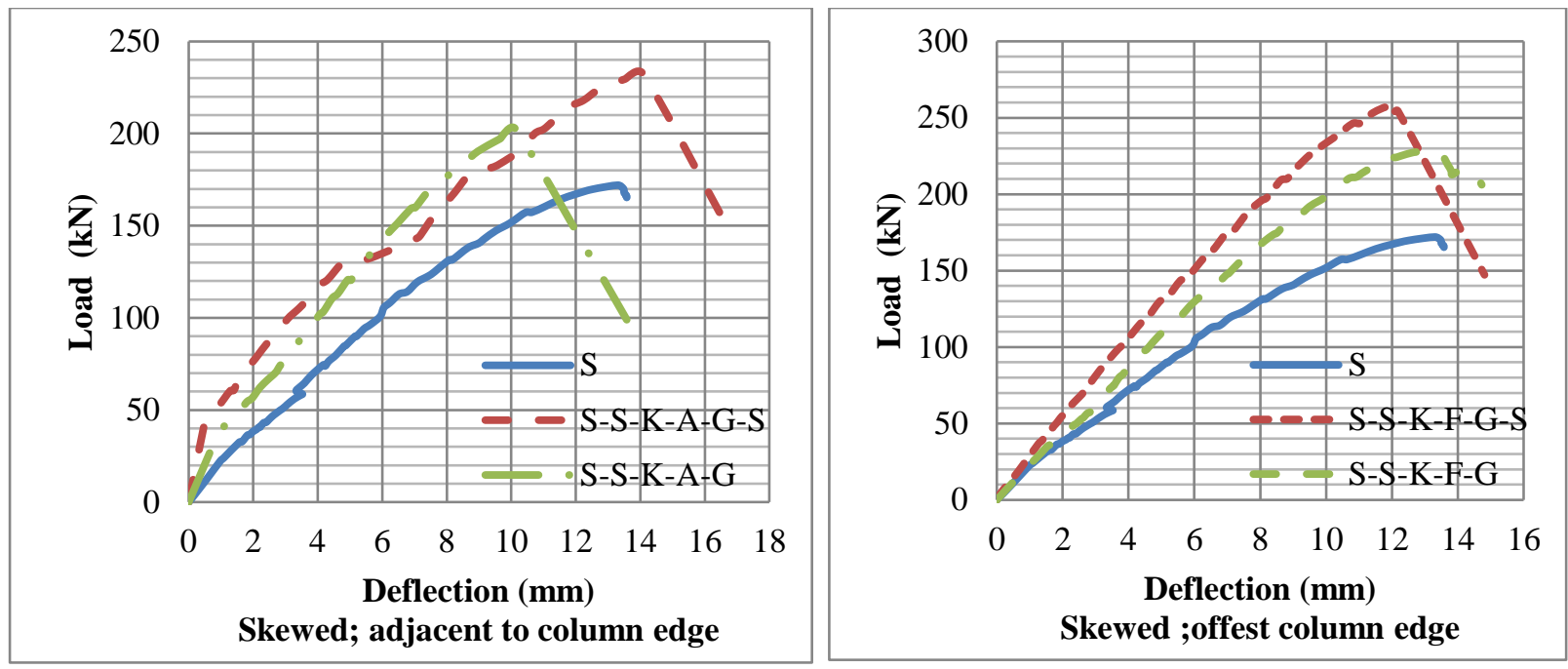

Fig.10. Central deflection comparison based on the effect of studs
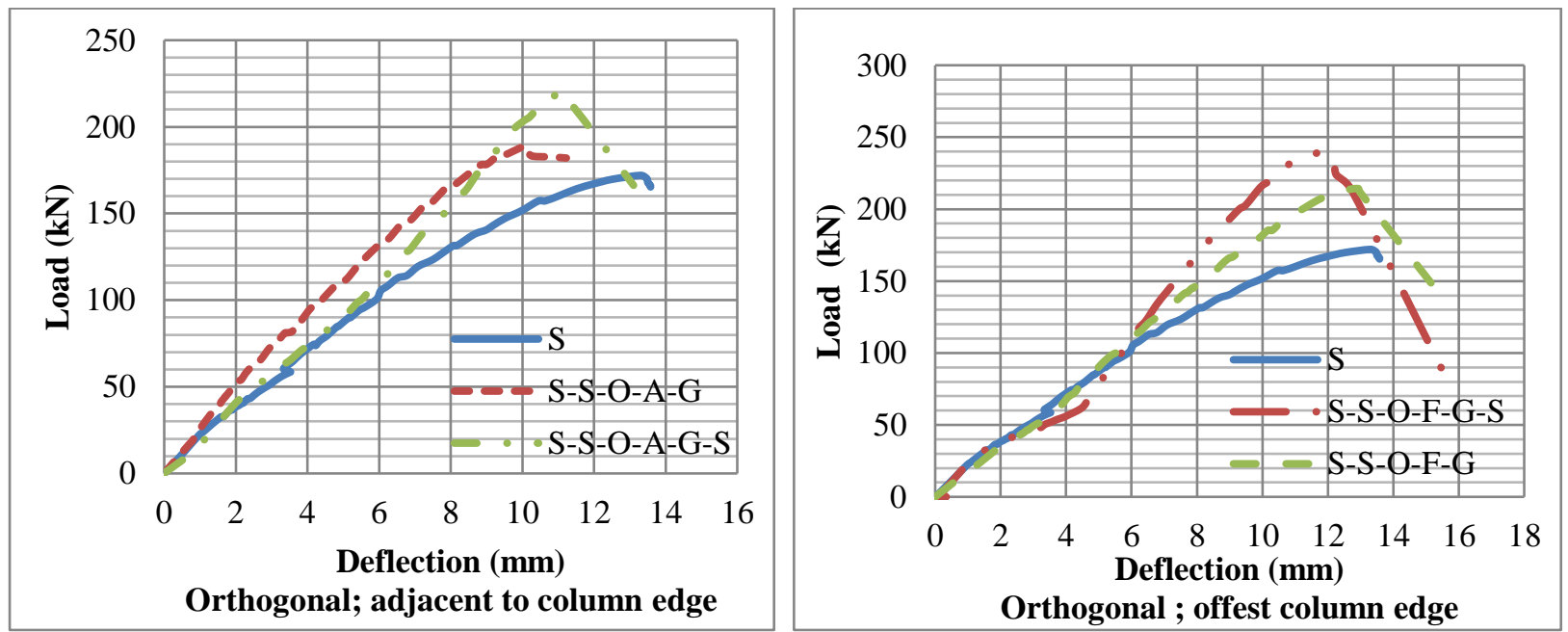

Fig.11. Central deflection comparison based on the effect of studs

\subsection{Load carrying capacity}

The cracking load $\left(\mathrm{P}_{\mathrm{cr}}\right)$, the ultimate load $\left(\mathrm{P}_{\mathrm{u}}\right)$, and the gain in the $\mathrm{Pu}$ for the strengthened specimens compared with the control specimen are listed in Table 3. $\mathrm{P}_{\mathrm{cr}}$ for the specimens strengthened externally by FRP strips was slightly improved in comparison with the control specimen. On the other hand, the strengthening using EB with studs' effectively enhanced, where $\mathrm{P}_{\mathrm{cr}}$ increased in comparison with the control specimen by $45-50 \%$ and 23.5-32\% for orthogonal and skewed respectively. The ultimate load capacity for all strengthened specimens had a notable increase, where the gain in $\mathrm{P}_{\mathrm{u}}$ was $10-48 \%$. The increase in $\mathrm{P}_{\mathrm{u}}$ for the specimens strengthened with $\mathrm{EB}$ with studs over the control specimen was $28-48 \%$. While the increase in $\mathrm{P}_{\mathrm{u}}$ was only $10-32 \%$ for specimens strengthened with EB-FRP strips. Thus, the increase in $\mathrm{P}_{\mathrm{u}}$ for the specimens which strengthened with Glass, Carbon and Steel plate over the control specimen was $6-22 \%$. The This article can be downloaded from here: www.ijaems.com increase in $\mathrm{P}_{\text {cr }}$ for the specimens strengthened with $\mathrm{EB}$ with studs over the control specimen was $31-51 \%$. While the increase in $\mathrm{P}_{\mathrm{cr}}$ was only $23-47 \%$ for specimens strengthened with EB-FRP strips. Thus, The increase in $\mathrm{P}_{\mathrm{cr}}$ for the specimens which strengthened with Glass, Carbon and Steel plate over the control specimen was 4-14\% it can be concluded that using EB with studs technique for strengthening slabs has well-contributed in increasing the punching shear capacity of slab-column connections than using EB technique.

Considering the strengthening arrangement, it can be noted that the skewed strengthening arrangement produced a slight increase in $\mathrm{P}_{\mathrm{u}}$, compared to the orthogonal arrangement.

Comparing the different locations of strips from the column face, it can be noted that the strips placed offset to column face with spacing equal slab depth gave relatively higher increase in $\mathrm{P}_{\mathrm{u}}$ compared to the strips placed

(C)2022 The Author(s). Published by Infogain Publication.

This work is licensed under a Creative Commons Attribution 4.0 License. http://creativecommons.org/licenses/by/4.0/ 
adjacent to column face. For specimens with orthogonal strengthening arrangement, the strips which located offset column face $\mathrm{P}_{\mathrm{u}}$ increase $8.8 \%$ than specimen which located adjacent to column face. Similar, for the specimens with skewed strengthening arrangement, the strips which located offset column face $\mathrm{P}_{\mathrm{u}}$ increase $9.4 \%$ than the specimen which strips placed adjacent to column face. The specimen which strengthened by external plate at the center of the slab has $22 \%$ increase than control specimen Figure.12 shows a comparison between $\mathrm{P}_{\mathrm{cr}}$ and $\mathrm{P}_{\mathrm{u}}$ for all tested specimens.
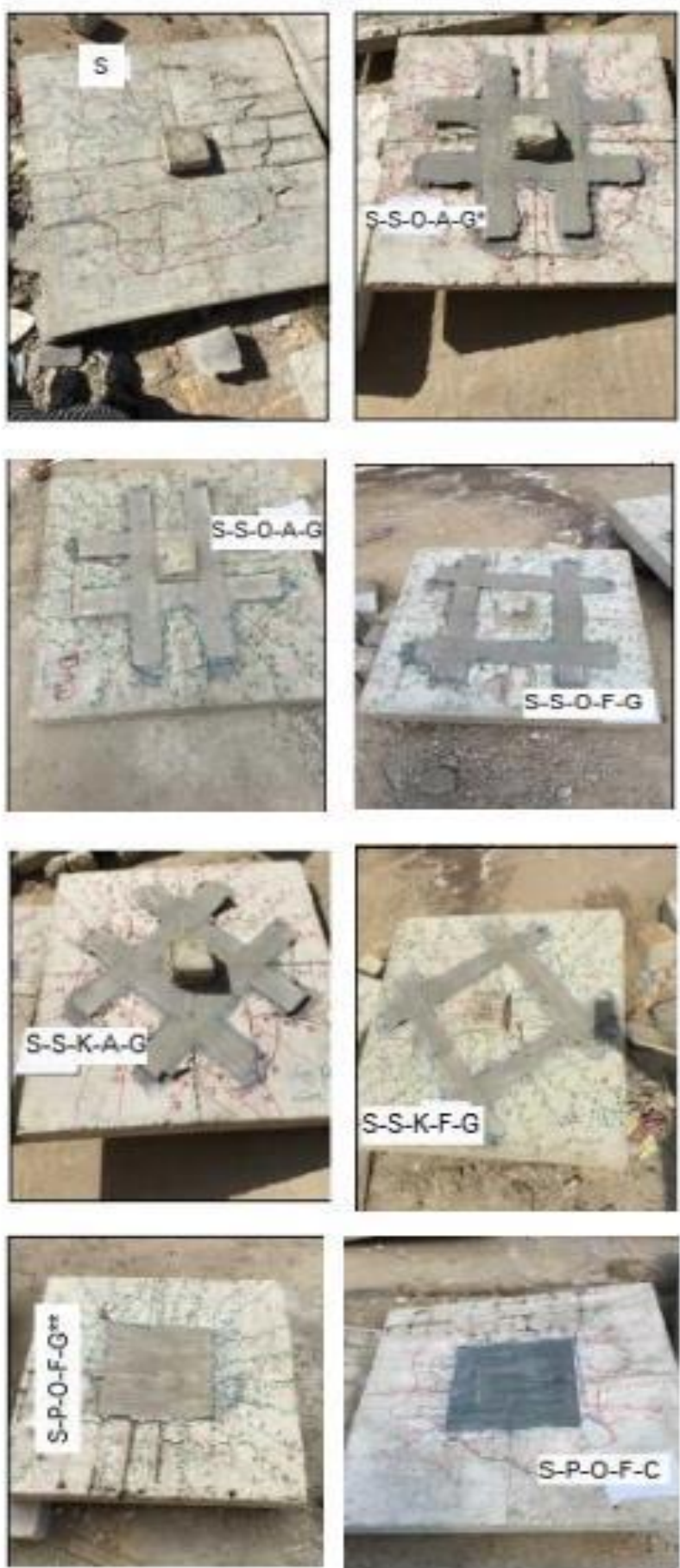
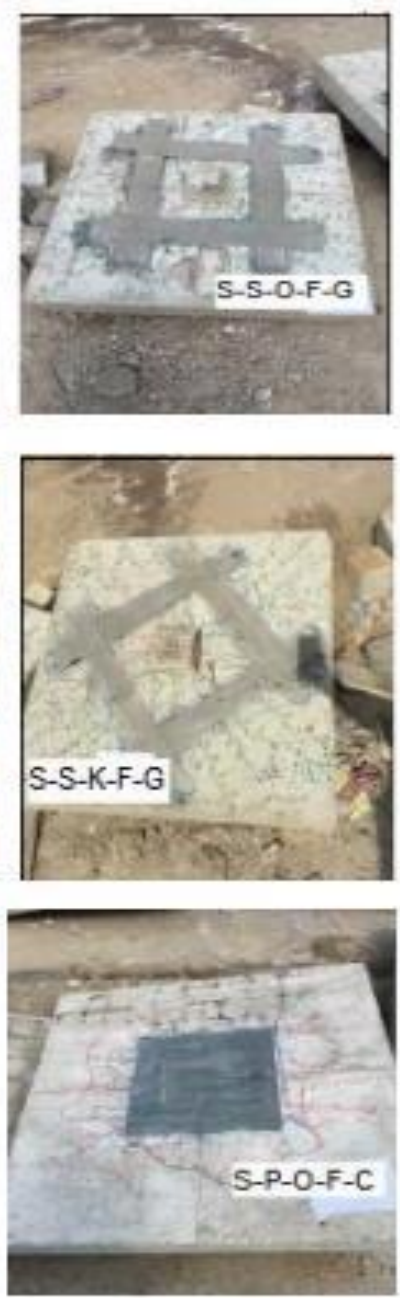
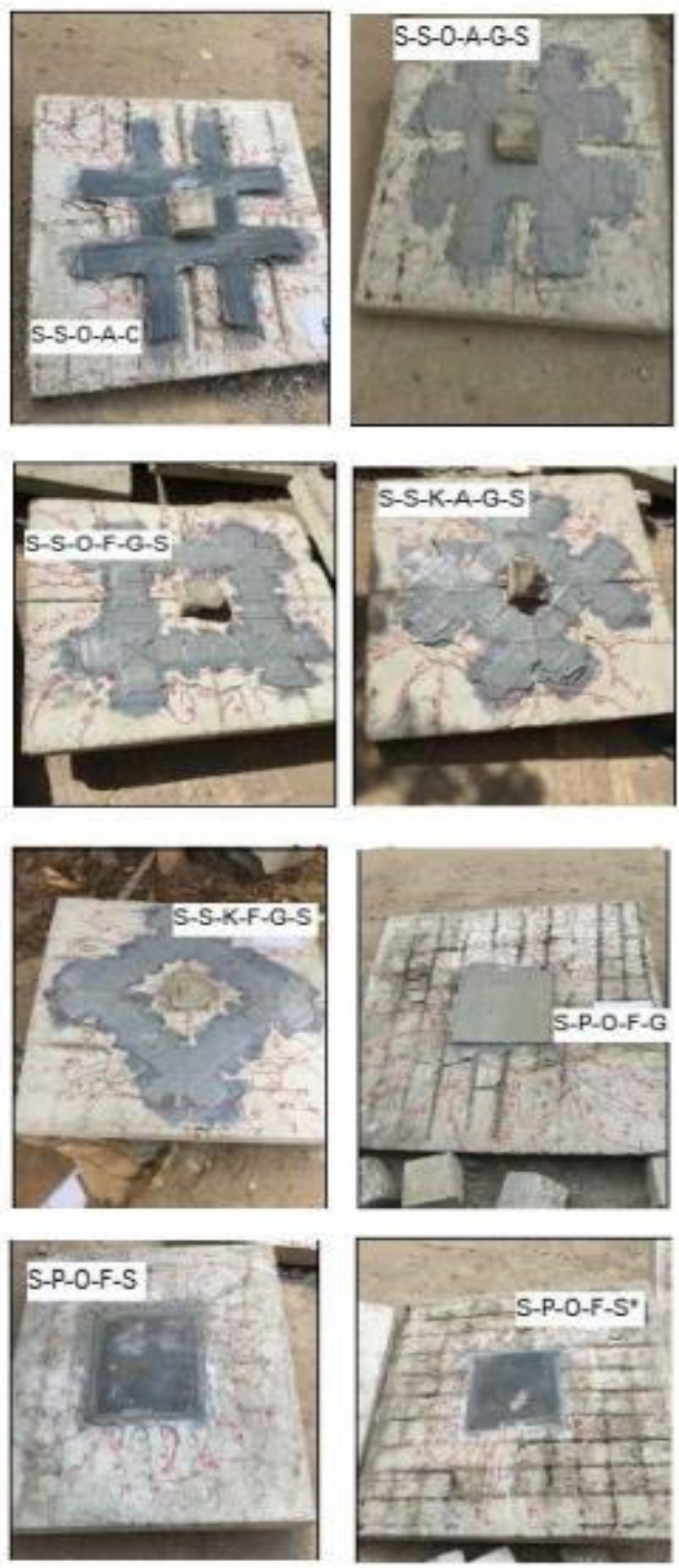

Fig.13. Crack pattern at failure load for the test specimens (bottom faces

\subsection{Stiffness}

The un-cracked stiffness $\left(\mathrm{K}_{\mathrm{i}}\right)$ and the ultimate stiffness
$\left(\mathrm{K}_{\mathrm{u}}\right)$ had been calculated for tested specimens from the load and deflection values at cracking and ultimate loads, 
as presented in Table 3. It shows $k_{i}$ increased for all strengthened specimens up to $69 \%$ compared to the control specimen. On the other hand, $\mathrm{Ku}$ affected by the strengthening technique. Where, Ku effectively increased for specimens strengthened using EB with studs by 33$58 \%$, and slightly increased for specimens with EB-FRP strips up to $52 \%$ compared to the control specimen.

Considering the effect of strengthening arrangement, the skewed strengthening arrangement showed higher stiffness compared to the orthogonal arrangement. The results indicate that $\mathrm{Ku}$ was less affected by strengthening arrangement than $\mathrm{Ki}$.

\subsection{Crack Propagation and Failure Characteristics}

Cracking pattern and distribution at failure at the bottom face of the slabs for all tested specimens are shown in Figure. 13. The failure mode for all specimens was punching shear. The control specimen exhibited flexural cracks that started near the column stub and extended towards the slab edges, especially towards the corners as the applied load increased. The failure was sudden, immediately after the specimen reached its ultimate capacity, and followed by a sharp drop in the load exerted to the control specimen. The punching shear failure plane on the bottom face can be easily seen around the column and at distances from its face ranged from $160 \mathrm{~mm}$ to the slab edges $(450 \mathrm{~mm})$ and associated with separation from the slab surface.

For the strengthened specimens, the flexural cracks started outside the strengthened strips which located adjacent column face, or flexural cracks started near the column face and did not propagate through the strengthened strips when the strips located offset column face. Similar to the control specimen, the flexural cracks propagated towards the slab edges. Reducing the spread of flexural cracks in the punching shear zone around the columns led to an increase in the punching shear capacity for the specimens. The distances from punching shear failure planes to the columns face were less than that for control specimen; especially for specimens strengthened with strips which located offset column face with spacing t. The specimens strengthened using strips suffered from premature debonding of FRP strips. As the load increased, some of FRP strips deboned from the bottom face of the slab and pulled away from the specimen with the concrete cover. At failure, strips deboned from the slab as the truncated concrete cone was pushed through the slab. Due to the FRP strips covered the zone around the column, the cracks at bottom face of the slabs were invisible.

\section{CALCULATED PUNCHING SHEAR CAPACITY}

The predicted punching shear capacity of the slabcolumn connections strengthened with FRP was obtained using the analytical model developed by Harajli and Soudki [11]. This model is based on that the punching capacity of slab-column connection increased with the increase in the flexural capacity of the slab. The FRP either EB with studs or EB strips is considered as additional reinforcement in the flexural capacity. For the FRP strengthened slab, the average moment capacity per unite width (m) was derived from the conventional equilibrium requirements for force and moment and the compatibility of strain along the depth of the slab section as follows:

$$
\begin{gathered}
m=\rho_{s} f_{y} d^{2}\left[1-0.59\left(\rho_{s} \frac{f_{y}}{f_{c}^{\prime}}+\rho_{f} \frac{k_{v} f_{f u} \frac{h}{d}}{f_{c}^{\prime}}\right)\right]+ \\
\rho_{f} k_{v} f_{f u} h^{2}\left[1-0.59\left(\rho_{s} \frac{f_{y} \frac{d}{h}}{f_{c}^{\prime}}+\rho_{f} \frac{k_{v} f_{f u}}{f_{c}^{\prime}}\right)\right] \quad \mathrm{Eq}(1) \\
\rho_{s}=\frac{A_{s}}{w_{d}}, \quad \rho_{f}=\frac{A_{f r p}}{W_{h}}
\end{gathered}
$$

Where $\rho_{\mathrm{s}}$ and $\rho_{\mathrm{f}}$ are the reinforcement ratio of the tension steel of the slap and FRP reinforcement either EB with studs or EB strip respectively; As is the area of the tension steel per slab width $w ; A_{f}$ is the area of FRP studs or strips; $h$ is the slab height; $f_{y}$ is the yield strength of steel reinforcement; $\mathrm{fc}$ " is the cylindrical concrete compressive strength $=0.8 \mathrm{f}_{\mathrm{cu}}$; and $\mathrm{Kv}$ is a factor which accounts for the ratio of stress development in FRP studs or strips at ultimate capacity of the specimens to the ultimate strength $\mathrm{f}_{\mathrm{fu}}$ of the studs or strips. According to Canadian standers (CSA-06) [12] . The factor $\mathrm{Kv}$ in Eq. (1) estimated as follows:

$$
K_{v}=\frac{K_{1} k_{2} L_{e}}{11,900 \epsilon_{f u}} \leq 0.75
$$

In which $\mathrm{K} 1$ and $\mathrm{K} 2$ are factors which represent for the concrete strength and wrapping method, respectively, and Le is the active bond length, where the bond stress is maintained. The factors are given as:

$\mathrm{K}_{1}=\left(\frac{\mathrm{f}_{\mathrm{c}}^{\prime}}{27}\right)^{\frac{2}{3}}$

$\mathrm{K}_{2}=\frac{L_{f}-2 L e}{L_{f}}$

$\mathrm{L}_{e}=\frac{25,350}{\left(\mathrm{t}_{\mathrm{f}} \mathrm{E}_{f}\right)^{0.58}}$

Where, $\mathrm{L}_{\mathrm{f}}$ is the dimension of the slab in the direction of FRP studs or strips; $t_{f}$ is the thickness of FRP strip or the diameter of FRP studs and $E_{f}$ is the elasticity modulus of FRP either studs or strip. 
Table 4.Comparison of experimental and predicted results.

\begin{tabular}{|c|c|c|c|}
\hline Slab ID & $\mathbf{P}_{\text {cal }}(\mathrm{KN})$ & $P_{\exp }(\mathrm{KN})$ & $\frac{\mathbf{P}_{\text {cal }}}{\mathbf{P}_{\text {exp }}}$ \\
\hline S-S-O-A-G-S & 192.19 & 188.79 & 1.02 \\
\hline S-S-O-A-C & 192.73 & 195.25 & 0.99 \\
\hline S-S-O-A-G & 189.06 & 191.49 & 0.99 \\
\hline S-S-O-A-G* & 190.695 & 220.69 & 0.86 \\
\hline S-S-O-F-G-S & 201.63 & 240.30 & 0.84 \\
\hline S-S-O-F-G & 194.83 & 214.29 & 0.91 \\
\hline S-S-K-A-G-S & 195.00 & 232.49 & 0.84 \\
\hline S-S-K-A-G & 190.41 & 202.20 & 0.94 \\
\hline S-S-K-F-G-S & 205.08 & 257.34 & 0.80 \\
\hline S-S-K-F-G & 197.61 & 227.69 & 0.87 \\
\hline S-P-O-F-G & 188.19 & 183.10 & 1.03 \\
\hline S-P-O-F-G* & 188.19 & 202.10 & 0.93 \\
\hline S-P-O-F-C & 191.13 & 210.0 & 0.91 \\
\hline S-P-O-F-S & 188.48 & 192.0 & 0.98 \\
\hline S-P-O-F-S* & 188.48 & 205.10 & 0.92 \\
\hline Mean & & & 0.92 \\
\hline Standard deviation & & & 0.07 \\
\hline
\end{tabular}

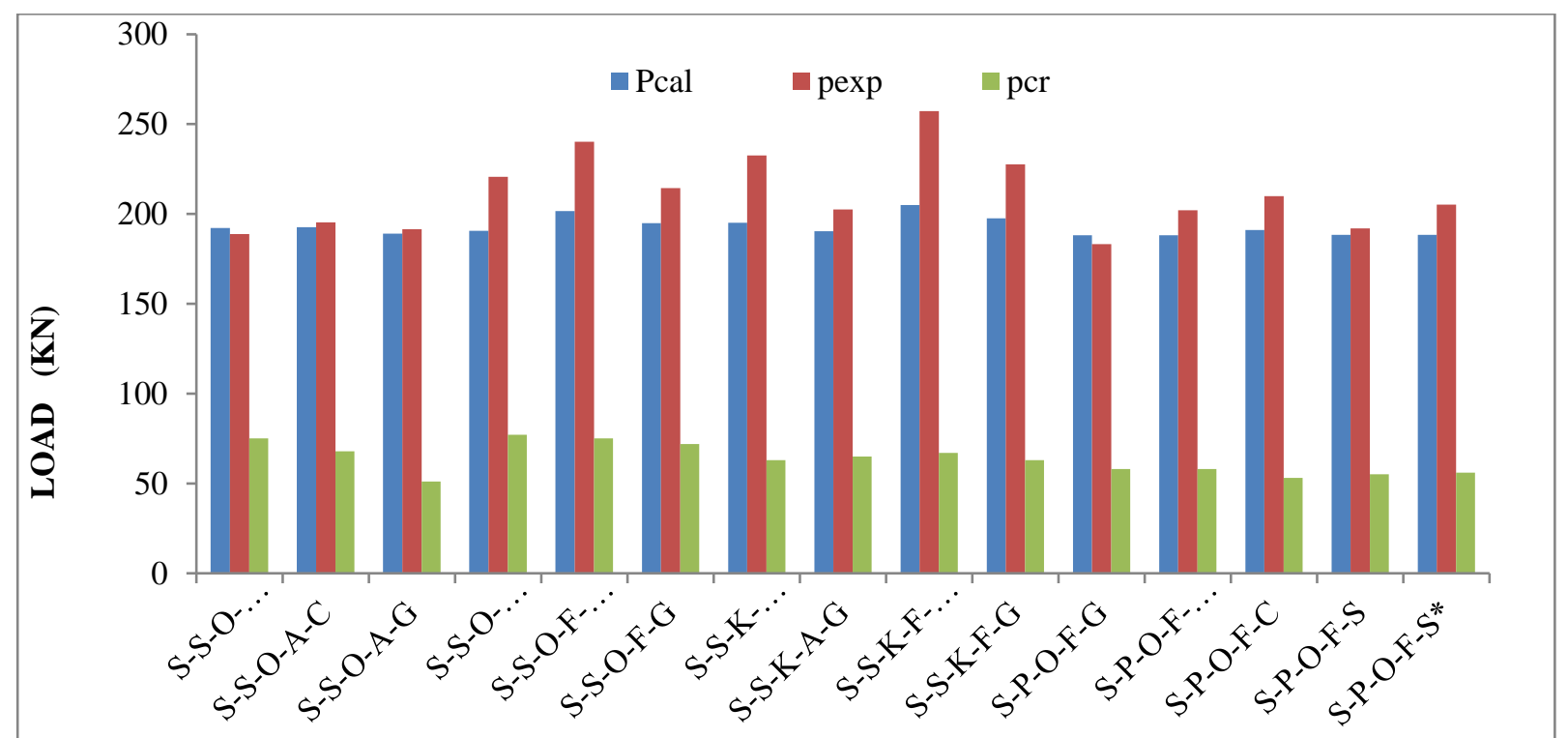

Fig.12. Comparison between cracking load, experimental ultimate load and calculated ultimate.

The area of FRP studs or strips was modified by Sharaf, et al. [13] to include the effect of the strengthening schemes, amount and spacing of FRP studs or strips as follows:

$$
\begin{aligned}
& \mathrm{A}_{\mathrm{f}}=\sum_{i}^{n}=1 \frac{n}{\xi} b_{f i} t_{f i} \\
& \eta=\cos \theta \\
& \xi=\frac{\sum_{\mathrm{i}}^{\mathrm{n}}=1 \frac{\mathrm{b}_{\mathrm{fi}}}{S_{i}}}{\eta}
\end{aligned}
$$$$
\mathrm{Eq}(7)
$$ 
In which $\eta$ is a factor which accounts for the effect of the orientation of FRP studs or strips; $\theta$ is the orientation of FRP to the slab reinforcement; $\Delta$ is considered 1 for orthogonal strengthening and 2 for skewed strengthening; and $£$ is a factor that accounts for the effect of FRP locations relative to the column face, the spacing between FRP studs or strips and the number of FRP studs or strips; $b_{f}$ is the width of FRP strip or the diameter of FRP studs; $s$ is the distance from the center of each FRP studs or strip to the column face; and $\mathrm{n}$ is the number of FRP studs or strips per slab width.

The flexural capacity of the slab can be estimated from the average moment capacity per unite width (m) using yield line analysis (Elsner and Hognestad [14]) as follows:

$\mathrm{P}_{\text {flex }}=8 \mathrm{~m}\left(\frac{1}{1-r / w}-3+2 \sqrt{2}\right)$

Where $r$ is the width of a column or the side length of a loaded area. Mowrer and Vanderbilt [25] proposed equation to estimate the punching shear strength $(\mathrm{Pu})$ of a flat slab as follows:

$\mathrm{P}_{\mathrm{u}}=\frac{0.8(1+d / r) b d \sqrt{f_{c}^{\prime}}}{1+\left(0.433 b d \sqrt{\overline{f_{c}^{\prime} / \mathrm{P}_{\text {flex }}}}\right)}$

In which $b$ is the perimeter of the column or the loaded area. The predicted punching shear capacity for the tested specimens calculated according to Eqs. (1)-(11) were compared with the experimental results as shown in Table 4 and Figure. 12. From comparison, it can be concluded that the proposed analytical model gave slightly underestimate for EB with studs strengthened specimens as the average ratio $\mathrm{P}_{\mathrm{u} \text {.calc }} / \mathrm{P}_{\mathrm{u} \text {.exp }}$ is 0.92 with a standard deviation of 0.07 .

\section{SUMMARY AND CONCLUSION}

In this study, EB with studs' technique was used to strengthen slab-column connections against punching shear failure. A FRP was installed surrounding the column at the bottom face of the slab. A total of sixteen square slabs with a concentric column were constructed and tested up to failure, one control specimen without strengthening, four specimens strengthened using EB with studs and eleven specimens strengthened using FRP strips externally bonded to the bottom face of the slab. For the considered strengthening techniques, the test variables were the strengthening arrangement relative to the orientation of the slab reinforcement and the strengthening location to the column face. Based on this investigation, the following conclusions may be drawn:

- The ultimate punching capacity was significantly increased for the specimens strengthened using EB with studs' technique over that strengthened using EB without studs Comparing with the control specimen, the punching capacity increased by $28-48 \%$ for specimens strengthened with EB with studs and on the other hand increased by 10 $32 \%$ for specimens strengthened with EB without studs.

- The stiffness of all strengthened specimens increased in un-cracked stage in the range from $3.6 \%$ to $69 \%$ than the control specimen. The stiffness in cracked stage was affected by the strengthening technique. Where, comparing with the control specimen the ultimate stiffness increased greatly by $33-58 \%$ for specimens strengthened using EB with studs. While the increasing in ultimate stiffness was 0.4-52\% for specimen strengthened using EB technique.

- All slabs failed in punching shear mode. The strengthened slabs experienced higher punching capacity compared with the control slab.

- Increasing the amount of FRP strips (number of layer) did not significantly increase the capacity of the slabs.

- Use different types of strengthened material is not effective in increasing punching capacity of the slabs.

- Increasing the size of FRP plates is effective where the specimen strengthened with GFRP plate with size $450 \mathrm{x}$ $450 \mathrm{~mm}$ increasing punching capacity $10.4 \%$ than GFRP plate with size $350 \times 350 \mathrm{~mm}$ and the specimen strengthened with steel plate with size 450 x $450 \mathrm{~mm}$ increasing punching capacity $6.8 \%$ than steel plate with size $350 \times 350$.

- The calculated punching shear capacities of the tested slabs using the recently developed analytical model, in which the two-way shear is expressed as a function of the flexural strength of the connection, agree well with the experimental results.

\section{REFERENCES}

[1] M. V. Malalanayake, J. P. Gamage and M. L. Silva , "Experimental investigation on enhancing punching shear capacity of flat slabs using CFRP," in 8th International Conference on Structural Engineering and Construction Management (ICSECM2017), Kandy, Sri Lanka, 2017.

[2] K. Soudki , A. K. El-Sayed and T. Vanzwol, "Strengthening of concrete slab-column connections using CFRP strips," Journal of King Saud University Engineering Sciences, vol. 24, no. 1, pp. 25-33, 2012.

[3] H. S. Askar, "Repair of R/C flat plates failing in punching by vertical studs," Alexandria Engineering Journal, vol. 54, no. 3, pp. 541-550, 2015.

[4] F. R. Miguel, M. Aurelio and K. Jakob, "Strengthening of flat slabs against punching shear using post-installed shear 
reinforcement," ACI Structural Journal, vol. 107, no. 4, pp. 434-442, 2010.

[5] H. Akhundzada, T. Donchev and D. Petkova, "Strengthening of slab-column connection against punching shear failure with CFRP laminates," Composite Structures, pp. 1-19, 21 September 2018.

[6] S. I. Attia, T. L. Lluís and S. H. E M, "Experimental and analytical investigation into the flexural performance of RC beams with partially and fully bonded NSM FRP bars/strips," Composite Structure, vol. 1225, pp. 113-126, 2015.

[7] S. ZY, W. G and L. YB, "Flexural strengthening of concrete beams with nearsurface-mounted steelfiberreinforced polymer composite bars," Composites, pp. 30-42, 2011.

[8] A. H. Abdel-Kareem, "Punching Strengthening of Concrete Slab-column Connections Using Near Surface Mounted (NSM) Carbon Fiber Reinforced Polymer (CFRP) Bars," Journal of Engineering Research and Reports, vol. 9, no. 2, pp. 1-14, 2019.

[9] A. H. Abdel-Kareem, A. S. Debaik, M. H. Makhlouf and M. Abdel-Baset, "Shear Strengthening of RC Beams with FRP using (NSM) Technique," Advances in Research, vol. 19, no. 4, pp. 1-20, 2019.

[10] M. Jalali, M. K. Sharbatdar, J. Fei Chen and F. J. Alaee, "Shear strengthening of RC beams using innovative manually made NSM FRP bars," Construction and Building Materials, vol. 36, pp. 990-1000, 2012.

[11] M. H. Harajli and K. A. Soudki, "Shear Strengthening of Interior Slab-Column Connections Using Carbon FiberReinforced Polymer Sheets," Journal of Composites for Construction, vol. 7, no. 2, May 2003.

[12] CSA Committee A23.3, "Design of concrete structure," Mississauga.Ontario,Canada, 2004.

[13] M. H. Sharaf, K. A. Soudki and M. V. Dusen, "CFRP Strengthening for Punching Shear of Interior Slab-Column Connections," Journal of Composites for Construction, vol. 10, no. 5, October 2006.

[14] Elstner RC and Hognestad E, "Shearing strength of reinforced concrete slabs," 1956. 